\title{
PENGARUH PEMBELAJARAN BERBASIS MULTIPLE INTELLIGENCES TERHADAP KESADARAN METAKOGNISI DAN HASIL BELAJAR IPA BIOLOGI SISWA KELAS VIII SMPN 11 MATARAM
}

\section{THE EFFECT OF MULTIPLE INTELLIGENCES BASED INSTRUCTION ON METACOGNITION AWARENESS AND BIOLOGY LEARNING OUTCOMES}

\author{
Siti Syifa'un Nufus ${ }^{1)}$, Jamaluddin'2), Imam Bachtiar ${ }^{3)}$ \\ ${ }^{1)}$ Mahasiswa Pendidikan Biologi FKIP Universitas Mataram \\ 2) 3) Dosen Pendidikan Biologi FKIP Universitas Mataram \\ Universitas Mataram, Jalan Majapahit No.62, Mataram, Indonesia \\ Email: sitisyifa.azzahra@gmail.com
}

Received: 11 Februari 2017; Accepted: 27 Maret 2017

\begin{abstract}
Abstrak. Pembelajaran berbasis multiple intelligences merupakan pembelajaran yang dapat mengakomodasi tumbuh dan berkembangnya kecerdasan jamak. Tujuan penelitian ini adalah untuk mengetahui pengaruh pembelajaran berbasis multiple intelligences terhadap kesadaran metakognisi dan hasil belajar IPA Biologi siswa. Jenis penelitian ini adalah eksperimen semu (quasy experiment). Populasi penelitian ini adalah siswa kelas VIII SMPN 11 Mataram tahun ajaran 2015/2016, dan penentuan sampel dilakukan dengan teknik non random sampling sehingga didapatkan kelas VIIIA sebagai kelas eksperimen dan kelas VIIIF sebagai kelas kontrol. Instrumen yang digunakan untuk mengukur pembelajaran berbasis multiple intelligences adalah lembar observasi keterlaksanaan RPP, kesadaran metakognisi diukur dengan rubrik MAI (Metacognitive Awareness Inventory) dan penilaian hasil belajar IPA Biologi menggunakan tes pilihan ganda. Data dianalisis menggunakan uji-t. Hasil penelitian menunjukkan bahwa pembelajaran berbasis multiple intelligences memberikan pengaruh yang lebih baik terhadap kesadaran metakognisi dan hasil belajar siswa kelas VIII SMPN 11 Mataram dibandingkan dengan pembelajaran konvensional.
\end{abstract}

Kata-kata Kunci: Pembelajaran Berbasis Multiple Intelligences, Kesadaran Metakognisi, Hasil Belajar IPA Biologi

\begin{abstract}
Multiple-Intelligences-Based (MIB) instruction is an instruction applied to encourage students' growth and development of multiple intelligence. This study aims to investigate the effect of MIB instruction theory on metacognition awareness and learning outcome in Biology instruction of students. A quasi experimental design was used. Non random sampling was applied based on the research population that covered the student of SMPN 11 Mataram, which resulted VIIIA as the experimental class and VIIIF as the controlled class. In order to determine the effect of MI-based instruction compared with traditional instruction, observation sheets were utilized to assess lesson plan accomplishment. In order to assess the metacognition awareness of the learners in Biology subject, the Metacognitive Awareness Inventory (MAI) was employed and to assess the Biology learning outcome that consisted of multiple-choice test. A t-test for independent sample was used to compare experimental and control groups post-test results. The results of the study indicated that MIB instruction had a significant effect on metacognition awareness and Biology learning outcome of VIII grade students of SMPN 11 Mataram compared with conventional instruction.
\end{abstract}

Keywords: Multiple-Intelligences-Based instruction, metacognition awareness, Biology learning outcome.

\section{PENDAHULUAN}

Pendekatan yang berpusat pada guru (teacher centered approach) cenderung mendominasi pelaksanaan pembelajaran saat ini. Sedangkan pendekatan yang berpusat pada siswa (student centered approach) baru merupakan teori dan konsep yang belum terintegrasi secara menyeluruh dalam rencana dan pelaksanaan pembelajaran [1]. Hal ini dapat diamati baik secara teoritis maupun praktis. Sehingga kreativitas, kemampuan berpikir kritis, dan penguasaan konsep siswa menjadi belum maksimal.

Saat ini berbagai rancangan pembelajaran yang berusaha mengembangkan sistem berpikir kritis, yang bersifat aplikatif, analisis, sintesis, dan kreatif belum terintegrasi dalam bagian-bagian esensial dari rancangan dan pelaksanaan pembelajaran [2]. Hal tersebut bukan saja menimbulkan proses pembelajaran yang pasif, melainkan juga menghasilkan peserta didik yang tidak memiliki keterampilan yang memadai. Sehingga siswa memiliki kemampuan, tetapi tidak 
dapat mengaplikasikan ilmu yang diperoleh dalam kehidupan sehari-hari.

Keterlibatan siswa secara aktif dalam pembelajaran dapat mengembangkan kreativitas siswa, dapat mengorganisasi cara berpikirnya, dan dapat menentukan sendiri strategi belajar yang digunakannya dalam menyelesaikan persoalan [3]. Hal ini berarti bahwa kesadaran metakognisi siswa dapat meningkat. Istilah metakognisi pertama kali diperkenalkan John Flavel dari Stanford University pada tahun 1975 [4]. Chairani [5] menjelaskan bahwa kemampuan metakognisi adalah kemampuan yang dimiliki seseorang yang mengacu kepada kesadaran otomatis tentang pengetahuan dan kemampuan untuk mengontrol, memahami, dan memanipulasi proses kognitifnya sendiri. Dengan demikian kemampuan metakognisi seseorang mengarah kepada proses belajar dan cara belajar seseorang sehingga dapat diketahui informasi mengenai keberhasilan belajar sekaligus melakukan evaluasi terhadap kesalahan pembelajaran seseorang. Kesadaran metakognisi siswa akan berdampak pada kemampuan siswa dalam memahami dan menguasai konsep pelajaran, sehingga akan berpengaruh terhadap hasil belajarnya. Coutinho [6] dalam penelitiannya menemukan bahwa siswa dengan kesadaran metakognisi tinggi mempunyai hasil belajar yang lebih baik daripada siswa dengan kesadaran metakognisi rendah.

Kesadaran metakognisi dan hasil belajar siswa dapat ditingkatkan dengan mengubah teknik pembelajaran, salah satu caranya adalah dengan menggunakan pembelajaran berbasis multiple intelligences [2]. Pembelajaran ini mengaplikasikan teori multiple intelligences dalam proses pembelajaran. Dengan demikian, semua materi pelajaran dapat disampaikan secara menyenangkan dan lebih bermakna sesuai dengan kecerdasan siswa. Observasi awal di SMPN 11 Mataram menunjukkan bahwa pembelajaran IPA Biologi cenderung teacher centered, dimana guru menjelaskan materi dan siswa dituntut untuk mendengarkan atau menyimak penjelasan guru dari awal hingga akhir pembelajaran. Padahal dengan pembelajaran berbasis multiple intelligences dapat diprediksi akan memberikan kontribusi yang positif terhadap kemampuan siswa dalam mengatur proses berpikirnya (kesadaran metakognisi) yang tentunya akan berimplikasi pada hasil belajarnya.

Teori multiple intelligences yang dikembangkan oleh Howard Gardner secara resmi diperkenalkan pada tahun 1983 melalui bukunya yang berjudul Frames of Mind yang kemudian direvisi dengan Intelligence Reframed pada tahun 1999 [7]. Teori ini merupakan kajian baru dalam khazanah pendidikan dan dianggap sebagai teori yang pertama kali mengakui keberagaman kecerdasan manusia yang berbeda dengan pandangan sebelumnya tentang Intelligence
Quotient (IQ) yang hanya bersandar pada dua kecerdasan, yakni kecerdasan bahasa, dan logismatematis [8].

Gardner dan Hatch [9] menemukan tujuh macam multiple intelligences, yakni logismatematis, verbal-linguistik, musikal, visualspasial, jasmaniah-kinestetik, interpersonal, dan intrapersonal. Penelitian Gardner selanjutnya menambahkan satu kecerdasan lagi, sehingga terdapat delapan kecerdasan dalam diri manusia. Kecerdasan yang dimaksud adalah kecerdasan naturalistik, yakni kapasitas untuk mengenali dan mengelompokkan objek tertentu di lingkungan fisik sekitarnya, seperti binatang, tumbuhan, dan kondisi cuaca [10].

Penelitian dengan tujuan untuk mengetahui pengaruh pembelajaran dan pengaruh model pembelajaran tertentu telah banyak dilakukan, contohnya $[11,12,13]$. Namun penelitian mengenai pengaruh pembelajaran berbasis multiple intelligences masih baru, terutama di Universitas Mataram, tidak ditemukan adanya penelitian yang dilakukan oleh mahasiswa maupun dosen mengenai pembelajaran berbasis multiple intelligences (berdasarkan data dari Perpustakaan FKIP Unram, UPT Perpustakaan Unram dan Lemlit Unram). Oleh karena itu, dirasa perlu untuk melakukan penelitian tentang pengaruh pembelajaran berbasis multiple intelligences terhadap kesadaran metakognisi dan hasil belajar IPA Biologi siswa kelas VIII SMPN 11 Mataram.

\section{METODE PENELITIAN}

Jenis penelitian ini adalah eksperimen semu (quasi experiment). Desain penelitian yang digunakan adalah non equivalent control group design. Penelitian ini dilaksanakan pada bulan September 2015 sampai dengan Mei 2016. Proses pembelajaran dilaksanakan pada bulan Oktober November 2015 di SMPN 11 Mataram. Populasi dalam penelitian ini adalah siswa kelas VIII. Sampel ditentukan menggunakan non random sampling sehingga diperoleh kelas VIIIA sebagai kelas eksperimen yang diajarkan dengan pembelajaran berbasis multiple intelligences dan kelas VIIIF sebagai kelas kontrol yang diajarkan dengan pembelajaran konvensional. Walaupun sampel tidak dipilih secara random, tetapi dapat dianggap mewakili seluruh kelas VIII karena kelas sampel memiliki karakteristik yang sangat mirip (hampir sama). Materi yang diajarkan adalah fotosintesis dan gerak pada tumbuhan.

Variabel bebas dalam penelitian ini adalah pembelajaran berbasis multiple intelligences dan variabel terikatnya adalah kesadaran metakognisi dan hasil belajar IPA Biologi siswa. Instrumen penelitian yang digunakan yakni Lembar Observasi Keterlaksanaan RPP berupa check list keterlaksanaan sintaks pembelajaran yang diisi oleh 
observer, Metacognitive Awareness Inventory (MAI) yang terdiri dari 52 item pernyataan dengan pilihan jawaban benar-salah, dan Lembar tes hasil belajar IPA Biologi dalam bentuk soal pilihan ganda. Uji coba instrumen penelitian yang dilakukan adalah uji keterbacaan untuk MAI dan uji validitas serta uji reliabilitas dengan bantuan Microsoft Excel 2013 untuk lembar tes hasil belajar IPA Biologi. Analisis data diawali dengan uji normalitas dan uji homogenitas dengan bantuan Microsoft Excel 2016, kemudian dilanjutkan dengan uji hipotesis menggunakan uji-t.

\section{HASIL DAN PEMBAHASAN}

Penelitian ini diawali dengan menentukan dan mengkaji materi yang akan diajarkan kemudian disesuaikan dengan jenis kecerdasan dan aktivitas pembelajaran berbasis multiple intelligences. Materi yang diajarkan adalah fotosintesis dan gerak pada tumbuhan. Materi fotosintesis diajarkan dengan jenis kecerdasan intrapersonal (melakukan refleksi) dan kecerdasan logis-matematis (bereksperimen). Materi gerak pada tumbuhan diajarkan dengan jenis kecerdasan naturalistik (menggunakan tanaman sebagai alat peraga) dan kecerdasan logis-matematis (bereksperimen).

Sebelum perlakuan, kesadaran metakognisi dan hasil belajar IPA Biologi siswa tidak banyak berbeda antara kelas kontrol dan kelas eksperimen. Nilai rata-rata $( \pm$ SD) kesadaran metakognisi kedua kelas tersebut hampir sama, yakni 53,90 $( \pm 8,00)$ untuk kelas kontrol dan 54,78 $( \pm 8,63)$ untuk kelas eksperimen. Nilai rata-rata $( \pm \mathrm{SD})$ hasil belajar kedua kelas tersebut juga hampir sama, yakni 41,53 $( \pm 4,71)$ untuk kelas kontrol dan 41,67 $( \pm 5,56)$ untuk kelas eksperimen. Nilai rata-rata kesadaran metakognisi kedua kelas sample disajikan pada Gambar 1.

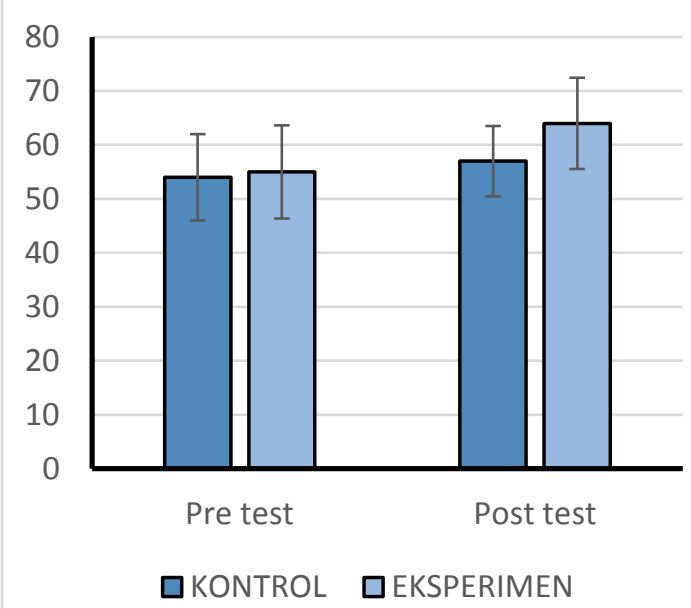

Gambar 1 Perbandingan Nilai Rata-Rata Kesadaran Metakognisi. Batang galat menunjukkan 1 SD.
Setelah dilaksanakan perlakuan, kesadaran metakognisi antara kedua kelas menunjukkan perbedaan yang lebih besar. Nilai rata-rata $( \pm S D)$ kesadaran metakognisi kelas kontrol adalah 57,17 $( \pm 6,51)$ dan kelas eksperimen $64,47( \pm 8,45)$. Hal yang sama juga dijumpai pada hasil belajar IPA Biologi. Nilai tertinggi di kelas eksperimen adalah 86 dan terendah 62 . Nilai rata-rata $( \pm S D)$ hasil belajar kelas kontrol adalah 70,47 $( \pm 5,32)$ dan kelas eksperimen 75,53 $( \pm 5,62)$. Nilai rata-rata hasil belajar IPA Biologi disajikan pada Gambar 2 .

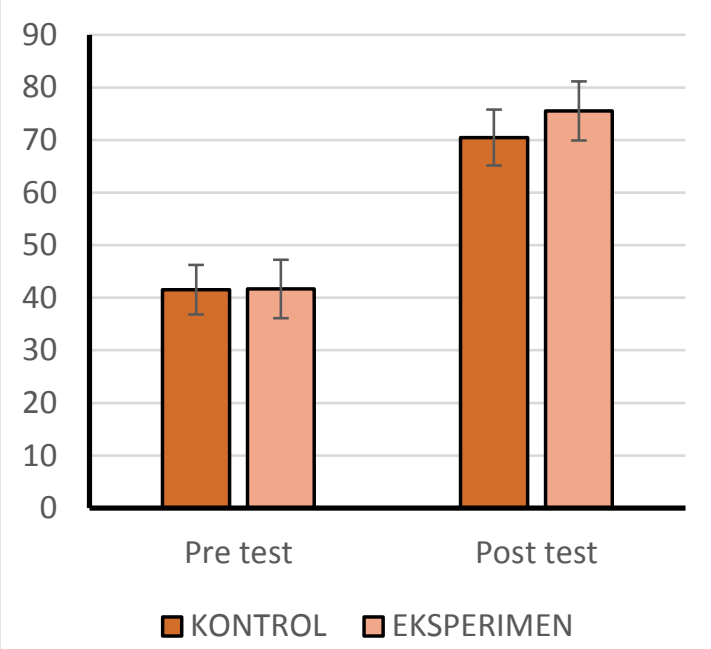

Gambar 2 Perbandingan Nilai Rata-Rata Hasil Belajar IPA Biologi. Batang galat menunjukkan 1 SD.

Dalam penelitian ini, dilakukan uji tambahan yakni uji perbedaan gain untuk mengetahui kelompok siswa dengan gain tertinggi. Apakah gain tertinggi terjadi pada kelompok siswa rendah, sedang, atau tinggi. Perbandingan gain kesadaran metakognisi siswa menunjukkan bahwa rata-rata $( \pm$ SD) gain ketiga kelompok mempunyai variasi yang sangat besar. Di kelas kontrol, siswa dengan kesadaran metakognisi rendah mempunyai gain rata-rata $6,33( \pm 3,09)$, siswa dengan kesadaran metakognisi sedang mempunyai gain dengan ratarata 3,62 $( \pm 4,27)$, dan siswa dengan kesadaran metakognisi tinggi mempunyai gain dengan ratarata $0,07( \pm 2,89)$. Di kelas eksperimen siswa dengan kesadaran metakognisi rendah mempunyai gain rata-rata $12,60( \pm 6,22)$, siswa dengan kesadaran metakognisi sedang mempunyai gain dengan ratarata $12,13( \pm 8,68)$, dan siswa dengan kesadaran metakognisi tinggi mempunyai gain dengan ratarata $4,35( \pm 5,81)$.

Perbandingan gain hasil belajar IPA Biologi siswa menunjukkan bahwa rata-rata $( \pm \mathrm{SD})$ gain ketiga kelompok juga mempunyai variasi yang sangat besar. Di kelas kontrol, siswa dengan kemampuan rendah (KR) mempunyai gain dengan rata-rata 30,40 $( \pm 3,86)$, siswa dengan kemampuan sedang (KS) mempunyai gain dengan rata-rata 29,33 
$( \pm 4,69)$, dan siswa dengan kemampuan tinggi (KT) mempunyai gain dengan rata-rata 27,27 $( \pm 4,22)$. Di kelas eksperimen, siswa dengan kemampuan rendah (KR) mempunyai gain dengan rata-rata 39,56 $( \pm 5,27)$, siswa dengan kemampuan sedang (KS) mempunyai gain dengan rata-rata $34,00( \pm 7,11)$, dan siswa dengan kemampuan tinggi (KT) mempunyai gain dengan rata-rata 27,25 $( \pm 4,39)$. Perbandingan gain kesadaran metakognisi sisw disajikan pada Gambar 3.

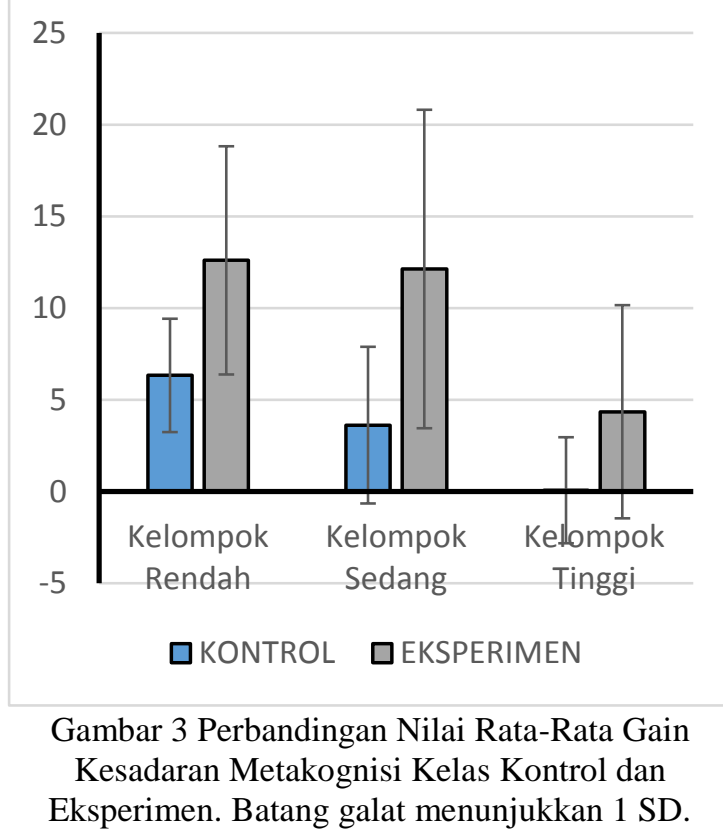

Berdasarkan hasil analisis data diketahui bahwa kelompok siswa dengan kemampuan rendah (KR) sama dengan kelompok siswa dengan kemampuan sedang (KS) dan berbeda dengan kelompok siswa dengan kemampuan tinggi (KT) atau dapat dituliskan $(\mathrm{KR}=\mathrm{KS}>\mathrm{KT})$. Hasil belajar IPA Biologi siswa disajikan pada Gambar 4.

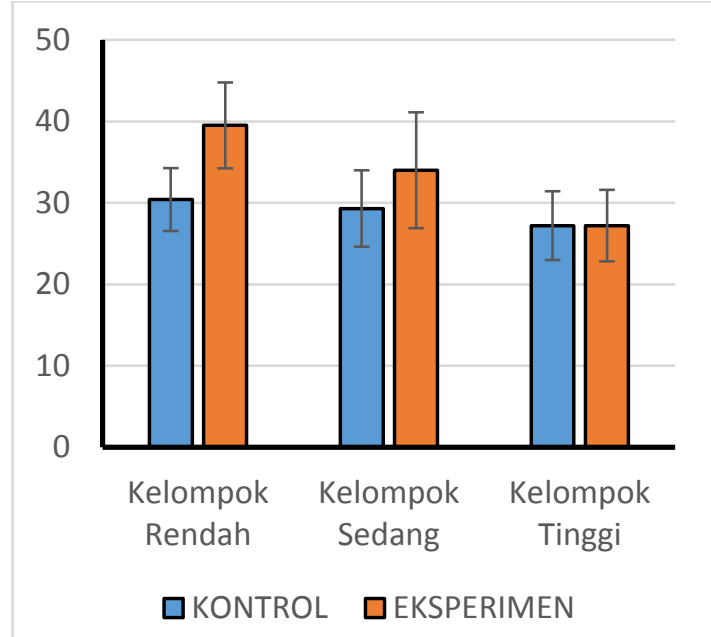

Gambar 4 Perbandingan Nilai Rata-Rata Gain Hasil Belajar IPA Biologi Siswa Kelas Kontrol dan Eksperimen. Batang galat menunjukkan 1 SD.
Hasil penelitian ini menunjukkan bahwa penerapan pembelajaran berbasis multiple intelligences (PMI) dan pembelajaran konvensional (PK) memberikan hasil yang berbeda pada pembelajaran IPA Biologi SMP. Kelompok siswa yang belajar dengan PMI memperoleh rata-rata skor kesadaran metakognisi dan hasil belajar lebih tinggi dibandingkan dengan siswa-siswa yang belajar dengan PK. Beberapa penelitian sebelumnya juga menemukan bahwa PMI memberikan pengaruh baik terhadap kesadaran metakognisi ataupun hasil belajar siswa SD [14], SMP [15], SMA $[16,17,18,19,20]$, dan mahasiswa [21].

Keunggulan PMI dibandingkan dengan PK (pembelajaran yang selama ini diterapkan di sekolah) dapat disebabkan karena kegiatan pembelajaran dengan PMI menjadi lebih bervariasi dan menyenangkan bagi siswa, sehingga siswa tidak mengalami kejenuhan dalam belajar. Pembelajaran ini juga dapat memfasilitasi tumbuh dan berkembangnya multiple intelligences dan mengembangkan metakognisi siswa.

Untuk mengembangkan metakognisi siswa, guru harus mampu menciptakan suasana kelas yang nyaman dan santai, menantang, menyenangkan, dan kebebasan siswa dalam berkreativitas dan berinteraksi dengan guru maupun dengan temannya [3]. PMI sangat berpotensi mengembangkan metakognisi siswa karena sintaks dalam PMI dapat mengakomodasi minat, bakat, dan keterampilan atau kreativitas siswa, sehingga PMI dapat diterapkan oleh guru sebagai variasi dalam pembelajaran.

Coutinho [6] menjelaskan bahwa metakognisi penting dalam belajar dan merupakan penentu penting dalam keberhasilan akademik siswa. Siswa yang memiliki metakognisi yang bagus memperlihatkan keberhasilan akademik yang bagus pula dibandingkan dengan siswa yang memiliki metakognisi yang kurang bagus. Metakognisi memungkinkan siswa cerdik dalam belajar, misalnya dengan mempelajari informasi yang lebih baru dibandingkan dengan informasi yang sudah dipelajari sebelumnya, siswa juga mampu mengatasi masalah-masalah atau kesulitan yang dihadapi ketika belajar dan dapat menemukan solusi dari masalah atau kesulitan yang dihadapi. Anggo [22] telah membuktikan bahwa kesadaran metakognisi sangat penting dalam pemecahan masalah dalam soal matematika. AlQibtia [23] juga menemukan bahwa siswa dengan kesadaran metakognisi tinggi dapat menulis paragraf deskripsi dengan baik, sedangkan siswa dengan kesadaran metakognisi sedang hingga rendah mengalami kesulitan dalam menulis paragraf deskripsi. Wilawan [24] membuktikan bahwa metakognisi berpengaruh baik terhadap kemampuan dan kesuksesan memahami teks bacaan.

Menurut Anderson dan Krathwohl (2001) dalam Danial [25], metakognisi merupakan aspek 
pengetahuan yang paling tinggi tingkatannya dalam taksonomi Bloom setelah faktual, konseptual, dan prosedural. Aktivitas metakognisi berbeda dari proses kognitif secara umum, metakognisi objek refleksinya adalah pengetahuan atau pemikiran pribadi yang dimiliki oleh seseorang. Nuryana dan Sugiarto [26] membuktikan bahwa metakognisi siswa berhubungan dan berpengaruh signifikan terhadap hasil belajar. Terkait dengan hubungan dan pengaruh metakognisi tersebut, beberapa penelitian sebelumnya juga menemukan bahwa metakognisi berhubungan dan berpengaruh sisgnifikan terhadap hasil belajar kognitif siswa SD [27], SMP [28], SMA [29,30] dan mahasiswa [31].

Beberapa hasil penelitian menunjukkan bahwa ketika siswa diajarkan menggunakan kemampuan berpikir tertentu, sesuai dengan gaya belajar dan jenis kecerdasan siswa, pencapaian hasil belajar mata pelajaran mereka meningkat secara signifikan [3]. Secara teoritis, pernyataan tersebut menunjukkan bahwa PMI berpeluang lebih besar dalam mengembangkan metakognisi dan hasil belajar siswa dibandingkan dengan PK. Hal tersebut terbukti dari hasil penelitian yang menunjukkan bahwa PMI memberikan pengaruh yang lebih baik atau signifikan terhadap kesadaran metakognisi dan hasil belajar siswa dibandingkan dengan PK.

PMI dapat diterapkan pada semua materi pelajaran, termasuk IPA Biologi. Untuk menerapkan pembelajaran ini, guru perlu mengkaji materi yang akan disampaikan untuk disesuaikan dengan jenis dan aktivitas PMI. Contohnya, guru akan mengajarkan materi struktur tumbuhan, pada materi tersebut terdapat banyak gambar yang akan dijelaskan oleh guru, jenis kecerdasan yang mengakomodasi gambar adalah kecerdasan visualspasial, maka guru dapat memilih PMI jenis kecerdasan visual-spasial. Selanjutnya, guru akan menyesuaikan materi dengan aktivitas pembelajaran, misalnya mewarnai gambar. RPP yang disusun oleh guru tentu menyesuaikan dengan sintaks PMI jenis kecerdasan visual-spasial. Mempelajari gambar yang dipadukan dengan warna akan memudahkan siswa untuk mengingat dan memahami materi yang banyak berkaitan dengan gambar. DePorter [3] menjelaskan bahwa informasi yang disampaikan dalam bentuk gambar berwarna akan lebih cepat tersimpan dalam memori. Demikian pula pada materi yang lainnya, dapat disesuaikan dengan jenis kecerdasan yang akan digunakan.

Kendala yang mungkin akan terjadi dalam menerapkan PMI ini adalah guru yang belum sepenuhnya paham mengenai delapan jenis kecerdasan manusia, sehingga akan mengalami kesulitan dalam memilih aktivitas pembelajaran dalam PMI. Namun jika hal tersebut dapat diatasi maka pembelajaran di kelas dengan PMI akan lebih menyenangkan dan berarti bagi guru maupun siswa. Di negara Finlandia yang terkenal sebagai negara dengan sistem pendidikan terbaik di dunia menurut Organization for Economic Cooperation and Development (OECD) tahun 2010 ternyata dalam pembelajaran di kelas sangat memperhatikan multiple intelligences siswa dan eksperimen (real work) bagi siswa jurusan sains. Sahlberg [32] dan Finnish National Board of Education [33] menjelaskan bahwa pembelajaran yang dilaksanakan dengan cara yang menarik, menyenangkan, dan sesuai bidang kecerdasan siswa akan menimbulkan rasa bahagia dan belajar akan menjadi sebuah hobi. Coppola [34] juga mengutarakan hal yang sama dan menekankan bahwa eksperimen (real work) lebih baik dibandingkan dengan pekerjaan rumah (homework). Dengan demikian, pembelajaran berbasis multiple intelligences dapat dijadikan referensi bagi guru dalam melaksanakan pembelajaran di dalam kelas.

\section{KESIMPULAN}

Berdasarkan hasil penelitian dan pembahasan, dapat disimpulkan bahwa pembelajaran berbasis multiple intelligences memberikan pengaruh yang lebih baik terhadap kesadaran metakognisi dan hasil belajar IPA Biologi siswa dibandingkan dengan pembelajaran konvensional dan gain kesadaran metakognisi serta hasil belajar IPA Biologi siswa tertinggi adalah pada kelompok rendah dan sedang.

\section{DAFTAR PUSTAKA}

[1] Suprijono, A. 2010. Cooperative Learning Teori \& Aplikasi Paikem. Yogyakarta: Pustaka Pelajar.

[2] Yaumi, M. 2012. Pembelajaran Berbasis Multiple Intelligences. Jakarta: Dian Rakyat.

[3] DePorter, B., Hernacki, M. 2013. Quantum Learning Membiasakan Belajar Nyaman dan Menyenangkan. Bandung: Kaifa Learning.

[4] Gama, C. A. 2004. Integrating Metacognition Instruction in Interactive learning Environments. Dissertation S3: University of Sussex.

[5] Chairani, Z. 2013. Aktivitas Metakognisi Sebagai Salah Satu Alat Untuk Meningkatkan Kemampuan Siswa dalam Pemecahan Masalah Matematika. Jurnal Riset Pendidikan Matematika 6 (5): 652-659.

[6] Coutinho, S. A. 2007. The Relationship between Goals, Metacognition, and Academic Success. Research Paper Northern Illinois University, United States of America 7 (1): 3947.

[7] Bílgín, E. K. 2006. The Effect of Multiple Intelligences Based Instruction on Ninth Graders Chemistry Achievement and Attitudes Toward Chemistry. Thesis S2: Midle East Technical University. 
[8] Gürçay, D. 2003. The Effect of Multiple Intelligences Based Instruction on Students' Physics Achievement. Thesis S2: The Middle East Technical University.

[9] Gardner, H., Hatch, T. 1989. Multiple Intelligences Go to School: Educational Implications of the Theory of Multiple Intelligences. Educational Researcher 18 (8): 4-10.

[10] Prasetyo, R., Andriani, Y. 2009. Multiply Your Multiple Intelligences. Yogyakarta: CV Andi Offset.

[11] Lolita, L. 2015. Pengaruh Pembelajaran Berbasis Inkuiri Terbimbing Terhadap Prestasi Belajar Kimia Materi Koloid pada Siswa Kelas XI IPA SMAN 7 Mataram. Skripsi S1. Universitas Mataram.

[12] Mutai, D. K., Changeiywo, J. M., Okere, M. I. 2014. Effects of Gowin's Vee Heuristic Strategy on Secondary School Students' Conceptual Understanding and Metacognition in the Topic of Moments in Physics, in Uasin Gishu County, Kenya. Journal of Education and Practice 5 (29): 193-206.

[13] Handayani, S. 2010. Eksperimentasi Pembelajaran Matematika dengan Menggunakan Model Struktural "Think-PairShare" Pada Materi Pokok Bentuk Akar dan Pangkat Ditinjau Dari Gaya Belajar Matematika Siswa. Tesis S2. Universitas Sebelas Maret.

[14] Saputra, T., Ambarita, A., Hamdan, Y. 2015. Pengaruh Strategi Pembelajaran Berbasis Multiple Intelligences Terhadap Hasil Belajar. Jurnal Pedagogi 15 (8): 237-243.

[15] Megandarisari. 2014. Pengaruh Pembelajaran Berbasis Multiple Intelligences Terhadap Motivasi Berprestasi Siswa pada Mata Pelajaran IPS di Kelas VIII SMPIT AlQudwah. Skripsi S1. Universitas Pendidikan Indonesia.

[16] Setyowati, M dan Hinduan, A. 2009. Penerapan Kecerdasan Majemuk Untuk Meningkatkan Hasil Belajar Fisika Peserta Didik di SMAN 2 Magelang, Jawa Tengah. Berkala Fisika Indonesia 1 (2): 27-31.

[17] Suhendri, H. 2011. Pengaruh Pembelajaran Berbasis Multiple Intelligences-Matematis Logis Terhadap Kemandirian Belajar dan Hasil Belajar Matematika. Jurnal Formatif 1 (1): 2939.

[18] Murdiyani, I. 2012. Pembelajaran Biologi Menggunakan Metode E-Learning Berbasis Multiple Intelligences pada Materi Sistem Gerak Manusia. Innovative Journal of Curriculum and Educational Technology 1 (1): 45-52.

[19] Eriando, G. 2013. Pengaruh Penerapan Pembelajaran Berbasis Multiple Intelligences Terhadap Hasil Belajar pada Materi Pelajaran
Biologi Kelas XI Semester 2 di SMAN 5 Yogyakarta. Jurnal Pendidikan Biologi 2 (5): 201-209.

[20] Wahyuni, S dan Pramukantoro, J. 2014. Perbandingan Model Pembelajaran Kooperatif Berbasis Multiple Intelligences dengan Kooperatif Tipe STAD Terhadap Hasil Belajar Siswa pada Standar Kompetensi Memahami Dasar-Dasar Kelistrikan di SMKN 3 Surabaya. Jurnal Pendidikan Teknik Elektro 3 (1): 245252.

[21] Liliawati, W., Rustaman, N. Y., Herdiwijaya, D., Rusdiana, D. 2013. Efektivitas Perkuliahan IPBA Terintegrasi Berbasis Kecerdasan Majemuk untuk Meningkatkan Penguasaan Konsep dan Menanamkan Karakter Diri Mahasiswa Calon Guru SMP pada Tema Tata Surya. Indonesian Journal of Applied Physics 3 (1): 63-71.

[22] Anggo, M. 2011. Perlibatan Metakognisi dalam Pemecahan Masalah Matematika. Edumatica 1 (1): 25-32.

[23] AlQibtia, M. 2013. Hubungan Kemampuan Metakognisi dengan Kemampuan Menulis Paragraf Deskripsi Siswa Kelas X SMA Negeri 2 Perbaungan Tahun Pelajaran 2012/2013. Jurnal Bastrindo Unimed 1 (1): 15-23.

[24] Wilawan, S. 2013. Enhancing EFL Reader' Metacognition. Journal of Education and Practice 4 (12): 64-73.

[25] Danial, M. 2010. Kesadaran Metakognisi, Keterampilan Metakognisi, dan Penguasaan Konsep Kimia Dasar. Jurnal Ilmu Pendidikan 17 (3): 225-229).

[26] Nuryana, E., Sugiarto, B. 2012. Hubungan Keterampilan Metakognisi dengan Hasil Belajar Siswa pada Materi Reaksi Reduksi Oksidasi (Redoks) Kelas X-1 SMA Negeri 3 Sidoarjo. Unesa Journal of Chemical Education 1 (1): 83-75.

[27] Basith, A. 2011. Hubungan Keterampilan Metakognitif dan Hasil Belajar Mata Pelajaran IPA pada Siswa Kelas IV SD dengan Strategi Pembelajaran Jigsaw dan Think Pair Share (TPS). Skripsi S1. Universitas Negeri Malang.

[28] Sudia, M., Budayasa, I. K., Lukito, A. 2014. Profil Metakognisi Siswa SMP dalam Memecahkan Masalah Terbuka. Jurnal Ilmu Pendidikan 20 (1): 86-93.

[29] Antika, L. T., Corebima, A. D., Mahanal, S. 2012. Perbandingan Keterampilan Metakognitif, Hasil Belajar Biologi, dan Retensi Antara Siswa Berkemampuan Akademik Tinggi dan Rendah Kelas X SMA di Malang. Jurnal Pendidikan Biologi 13 (4): 245-254.

[30] Ardila, C., Duran, A., Zubaidah, S. 2013. Hubungan Keterampilan Metakognisi Terhadap Hasil Belajar Biologi dan Retensi 
Siswa Kelas X dengan Penerapan Strategi Pemberdayaan Berpikir Melalui Pertanyaan (PBMP) di SMAN 9 Malang. Jurnal Pendidikan Biologi 13 (4): 222-232.

[31] Sumampouw, H. M. 2011. Keterampilan Metakognitif dan Berpikir Tingkat Tinggi dalam Pembelajaran Genetika (Artikulasi Konsep dan Verifikasi Empiris). Bioedukasi 4 (2): 23-39.
[32] Sahlberg, P. 2010. The Secret to Finland's Success: Educating Teachers. Scope 1 (1): 1-8.

[33] Finnish National Board of Education. 2013. Finnish Education, Education System, Vocational Education and Training, Technical Insulation. Finlandia: Finnish Ministry of Education and Culture.

[34] Coppola, B. P. 2015. Real work is better than Homework. Abstract ICMSE 2015: 3. 